\title{
PENERAPAN SISTEM INFORMASI PENGOLAHAN BARANG MILIK NEGARA DAN BAHAN PRAKTIKUM DI POLITEKNIK NEGERI INDRAMAYU
}

\author{
Ahmad Lubis Ghozali'), Muhamad Mustamiin' ${ }^{2)}$, Siti Hodizah' ${ }^{3)}$ \\ ${ }^{1,2,3)}$ Program Studi Teknik Informatika \\ Politeknik Negeri Indramayu \\ Jl. Lohbener Lama No.08, Lohbener, Kabupaten Indramayu, Jawa Barat 45252 \\ 1)lubis@polindra.ac.id
}

\begin{abstract}
ABSTRAK
Politeknik Negeri Indramayu adalah salah satu instansi pendidikan yang memiliki bagian pengadaan barang dan bahan praktikum di setiap jurusan. Bagian maintenance dan bengkel memiliki tugas pengadaan barang dan bahan praktikum sebagai sarana penunjang kegiatan untuk keperluan praktikum mahasiswa, jenis barang dan bahan praktikum dibagi menjadi dua yaitu barang tidak habis pakai dan barang habis pakai. Dengan tersedianya persediaan barang dan bahan praktikum maka diharapkan apa yang dibutuhkan oleh dosen, teknisi hingga mahasiswa dapat terpenuhi sehingga dapat memperlancar kegiatan para pengguna dan dapat menghindari terjadinya kekurangan barang dan bahan. Tetapi pengolahan barang dan bahan praktikum di setiap jurusan masih manual, dimana cara pencarian, serta peminjaman dan pengembalian masih menggunakan sistem tulis tangan. Pembuatan aplikasi rancang bangun pengolahan barang dan bahan praktikum di Politeknik Negeri Indramayu digunakan untuk mengelola persediaan barang dan bahan praktikum serta transaksi peminjaman dan pengembalian. Proses pembuatan program dimulai dari awal, yaitu analisa kegiatan admin, penyusunan flowchart, ERD, UML dan pembuatan tabel sampai pemrograman. Metode pengembangan sistem yang digunakan yaitu metode $S D L C$ model waterfall karena lebih terstruktur dan sistematis. Pengujian yang dilakukan yaitu menggunakan pengujian black box dan kuisioner yang dibagikan ke 15 koresponden. Pengujian black box menghasilkan aplikasi tidak ada yang error serta hasil jawaban kuisioner yang dibagikan ke 15 koresponden yaitu $83,33 \%$, dengan presentase tersebut dapat dikatakan aplikasi ini sudah amat baik digunakan oleh pengguna. Dari hasil penelitian menyimpulkan bahwa sistem pengolahan barang dan bahan praktikum ini menghasilkan $83,33 \%$ dan dapat dikatakan amat baik.
\end{abstract}

Kata Kunci: Sistem Informasi, peminjaman, pengembalian, barang dan bahan praktikum, web.

\begin{abstract}
Indramayu State Polytechnic is one of the educational institutions that have the procurement department of materials and practicum materials in each department. The maintenance and workshop section has the task of procuring practicum materials and materials as a means of supporting activities for the purposes of student practicum, the type of materials and practicum materials are divided into two: consumables and consumables. With the availability of supplies and practicum materials, it is expected that what is needed by the lecturers, technicians and students can be fulfilled so as to facilitate the activities of the users and to avoid shortages of goods and materials. But the processing of practicum goods and materials in each department is still manual, where the method of searching, as well as borrowing and returning is still using the handwriting system. The manufacture of processing and application materials for practicum materials at Indramayu State Polytechnic is used to manage the inventory of materials and practicum materials as well as loan and return transactions. The process of making the program starts from the beginning, namely the analysis of admin activities, preparation of flowcharts, ERD, UML and making tables until programming. The system development method used is the SDLC waterfall model method because it is more structured and systematic. The tests were carried out using black box testing and questionnaires distributed to 15 correspondents. Black box testing produces no error application and the results of the questionnaire answers distributed to 15 correspondents are $83.33 \%$, with this percentage can be said that this application has been very well used by users. From the results of the study concluded that the processing system of goods and materials of this lab produces $83.33 \%$ and can be said to be very good.
\end{abstract}

Keywords: Information System, borrowing, returns, practicum items and materials, web. 


\section{PENDAHULUAN}

Perkembangan ilmu dan teknologi yang berjalan dengan pesat, membuat salah satu instansi untuk berusaha mengatasi segala permasalahan yang timbul di sekitarnya. Melihat banyaknya keuntungan yang didapat dari penggunaan teknologi, mendorong semua instansi agar dapat menggunakan fasilitas.

Politeknik Negeri Indramayu (POLINDRA) adalah sebuah perguruan tinggi negeri yang terletak di Jl. Raya Lohbener Lama, Desa Lohbener, Kecamatan Lohbener, Kabupaten Indramayu. POLINDRA mempunyai 5 jurusan yaitu Teknik Informatika (D3), Teknik Mesin (D3), Teknik Pendingin dan Tata Udara (D3), Perancangan Manufaktur (D4), dan Rekayasa Perangkat Lunak (D4).

Mahasiswa POLINDRA diberikan fasilitas untuk praktik yang berbeda sesuai dengan jurusannya. Teknik Informatika mempunyai lab komputer. Sedangkan Teknik Mesin dan Teknik Pendingin mempunyai Bengkel. Masing-masing jurusan mempunyai kebutuhan stok barang dan bahan praktikum yang berbeda. Persediaan ini sangat dibutuhkan untuk menjamin kelancaran aktivitas praktik.

Saat ini sistem pengolahan barang dan bahan praktikum di setiap jurusan masih manual, dimana cara pencarian, peminjaman dan pengembalian masih menggunakan cara manual, seperti sistem peminjaman dan pengembalian yang masih mengunakan sistem tulis tangan. Dengan meningkatnya fungsi pengolahan stok barang di bengkel dan lab secara maksimal maka diharapakan juga akan memberikan pelayanan yang maksimal bagi mahasiswa, dosesn dan teknisi.

Salah satu langkah yang di terapkan untuk meningkatkan fungsi dari peminjaman barang dan bahan itu sendiri adalah sistem pengolah data barang dan bahan praktikum yang terkomputerisasi. Sistem informasi pengolahan data barang dan bahan praktikum di bengkel atau di lab yang dibutuhkan oleh Politeknik Negeri Indramayu nantinya dapat dipergunakan untuk pencarian barang, peminjaman, pengembalian, ganti rugi jika barang yang di pinjam itu hilang.

Dari penjelasan tersebut maka penulis tertarik membuat sebuah "Rancang Bangun Aplikasi Pengolahan Barang dan Bahan Praktikum di Politeknik Negeri Indramayu Berbasis Website". Sistem ini diharapkan akan mempermudah admin dalam pengolahan stok barang dan bahan praktikum. Dan bagian user untuk melihat jumlah stok barang dan bahan praktikum yang tersedia. Sehingga bisa mendapatkan informasi yang dibutuhkan dalam waktu yang relatif singkat.

\section{Landasan Teori dan Metodologi Penelitian 2.1 Personal Home Page (PHP)}

Menurut Agus Saputra (2011, p.1) PHP atau yang memiliki kepanjangan PHP Hypertext Prep rocessor merupakan suatu bahasa pemrograman yang di fungsikan untuk membangun suatu Website dinamis. PHP menyatu dengan kode HTML, maksudnya adalah beda kondisi. HTML digunakan sebagai pembangun atau pondasi dari kerangka layout web, sedangkan PHP difungsikan sebagai prosesnya sehingga dengan adanya PHP tersebut, web akan sangat mudah di-maintenance.

\section{2 ХАМPP}

XAMPP ialah perangkat lunak bebas yang mendukung banyak sistem operasi, merupakan campuran dari beberapa program. Yang mempunyai fungsi sebagai server yang berdiri sendiri (localhost), yang terdiri dari program MySQL Database, Apache HTTP Server, dan penerjemah ditulis dalam bahasa pemrograman PHP dan Perl.

\subsection{Flowchart}

Didalam rancang bangun aplikasi pengolahan barang dan bahan praktikum di Politeknik Negeri Indramayu berbasis website ini terdapat beberapa flowchart yaitu sisi user dan admin.

\subsubsection{Flowchart System Admin}

Flowchart system admin merupakan bagan yang menunjukan alur kerja admin dalam rancang bangun pengolahan barang dan bahan praktikum di Politeknik Negeri Indramayu secara keseluruhan dan berurutan sesuai posedur dalam sistem.

\subsubsection{Flowchart Program Admin}

Didalam flowchart aplikasi admin rancang bangun aplikasi pengolahan barang dan bahan praktikum di Politeknik Negeri Indramayu menggambarkan langkah-langkah penyelesaian masalah dari sisi admin.

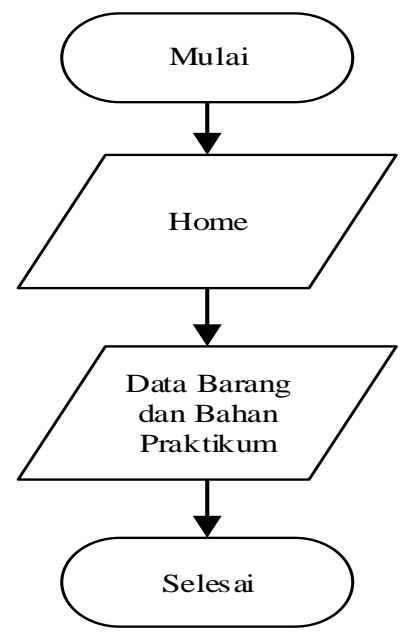

Gambar 1. Flowchart Aplikasi User 


\section{Hasil dan Pembahasan}

Penelitian ini menghasilkan sebuah website pengolahan barang dan bahan praktikum yang akan digunakan di bengkel atau maintenance. Website pengolahan barang dan bahan praktikum barang terdiri 2 pengguna yaitu admin dan anggota seperti mahasiswa, dosen dan teknisi. Website anggota hanya dapat melihat jumlah stok barang dan bahan praktikum yang tersedia di bengkel atau maintenance. Sedangkan website admin dapat melihat data informasi anggota, data barang, menambahkan stok barang masuk, mengurangi stok barang keluar, melakukan transaksi peminjaman dan laporan perbulan untuk pengembalian barang, laporan anggota serta laporan data barang.

\subsection{Pembahasan}

Setelah mengumpulkan, menganalisis, dan merancang maka penulis mengimplementasikan semuanya untuk terciptanya aplikasi Pengolahan Barang dan Bahan Praktikum di Politeknik Negeri Indramayu.

\subsection{Implementasi Desain Interface Aplikasi}

Implementasi Desain interface aplikasi pada penelitian kali ini dibagi menjadi 2 (dua) tahapan, yaitu untuk implementasi mahasiswa dan implementasi admin.

\subsubsection{Implementasi Desain Anggota}

Implementasi Desain Anggota ini diperuntukan user seperti mahasiswa, dosen dan teknisi untuk melihat stok data barang dan bahan praktikum yang tersedia.

\section{Halaman Home Anggota}

Halaman home anggota ini akan muncul pertama kali ketika anggota mengakses website pengolahan stok barang. Berikut adalah rancangan halaman home anggota dapat dilihat pada Gambar.

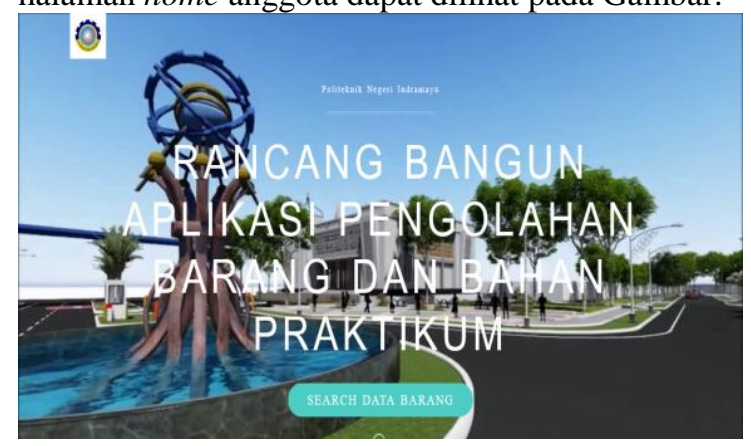

Gambar 2. Halaman Home Anggota

\section{Halaman Data Barang Anggota}

Halaman data barang anggota adalah halaman yang memberikan informasi tentang stok barang dan bahan praktikum yang tersedia di bengkel atau maintenance. Halaman ini akan muncul ketika mahasiswa mengklik button search data barang. Berikut adalah halaman data barang anggota dapat dilihat pada Gambar.

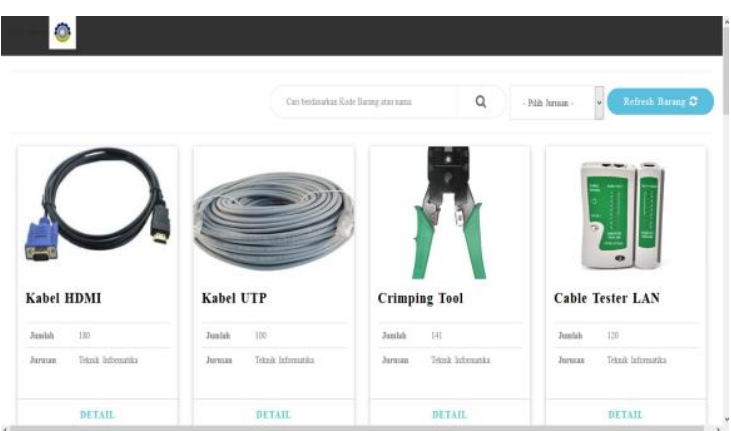

Gambar 3. Halaman Data Barang Anggota

\subsubsection{Implementasi Desain Admin}

Implementasi Desain Admin ini diperuntukan admin digunakan untuk menginputkan data anggota, data data barang dan bahan praktikum serta mencetak laporan.

\section{Halaman Login Admin}

Halaman login admin yaitu halaman yang akan tampil pertama kali serta admin harus mengisikan username dan password. Ketika admin salah menginputkan username dan password maka tidak akan masuk ke halaman selanjutnya. Halaman login admin dapat dilihat pada Gambar.

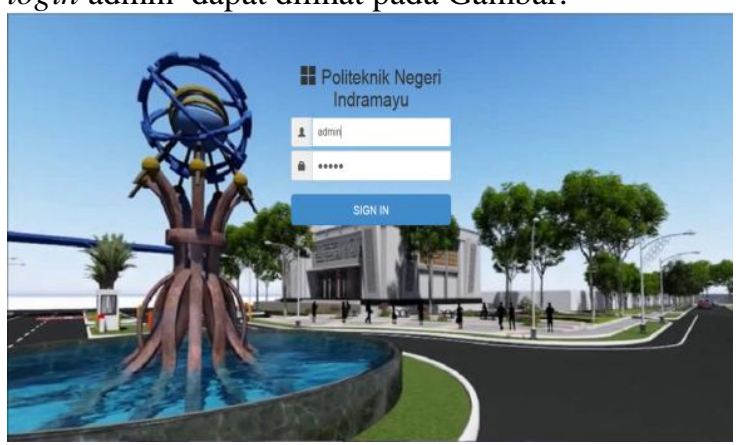

Gambar 4. Halaman Login Admin

\section{Halaman Dashboard Admin}

Halaman dashboard admin adalah halaman yang akan muncul setelah admin melakukan login. Halaman ini menampilkan informasi, berikut adalah halaman dashboard admin dapat dilihat pada Gambar.

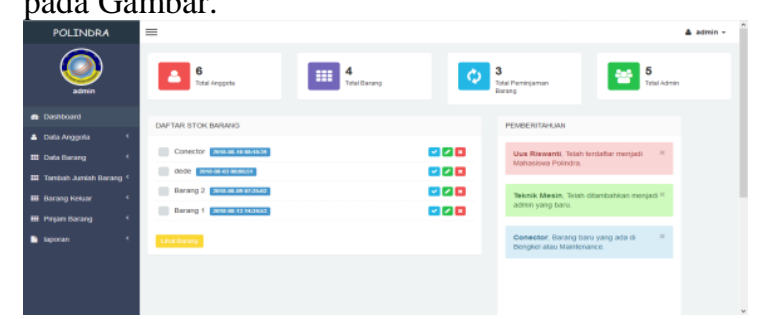

Gambar 5. Halaman Dashboard Admin

\section{Halaman Data Anggota Mahasiswa}

Halaman data anggota mahasiswa adalah informasi tentang data-data anggota mahasiswa Politeknik Negeri Indramayu yang telah diinputkan oleh admin melalui form data anggota. Berikut adalah halaman data anggota mahasiswa dapat dilihat pada Gambar. 


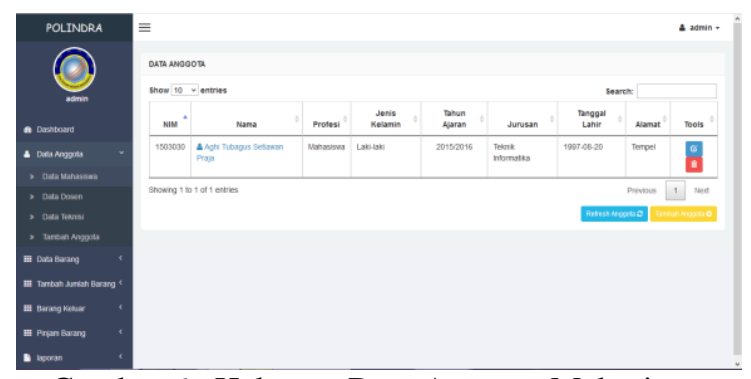

Gambar 6. Halaman Data Anggota Mahasiswa

\section{Halaman Data Anggota Dosen}

Halaman data anggota dosen adalah informasi tentang data-data anggota dosen Politeknik Negeri Indramayu yang telah diinputkan oleh admin melalui form data anggota. Berikut adalah halaman data anggota dosen dapat dilihat pada Gambar.

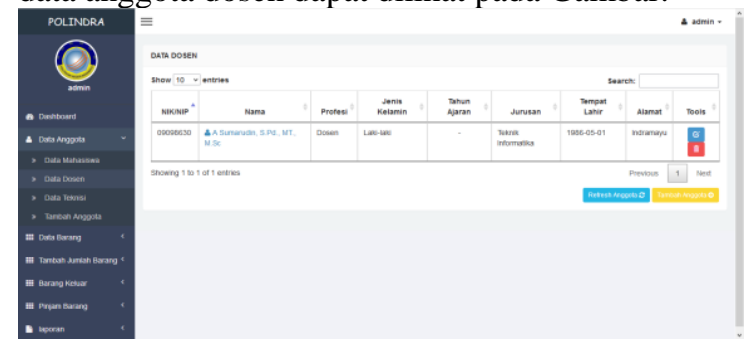

Gambar 7. Halaman Data Anggota Dosen

\section{Halaman Data Anggota Teknisi}

Halaman data anggota teknisi adalah informasi tentang data-data anggota teknisi Politeknik Negeri Indramayu yang telah diinputkan oleh admin melalui form data anggota. Berikut adalah halaman data anggota teknisi dapat dilihat pada Gambar.

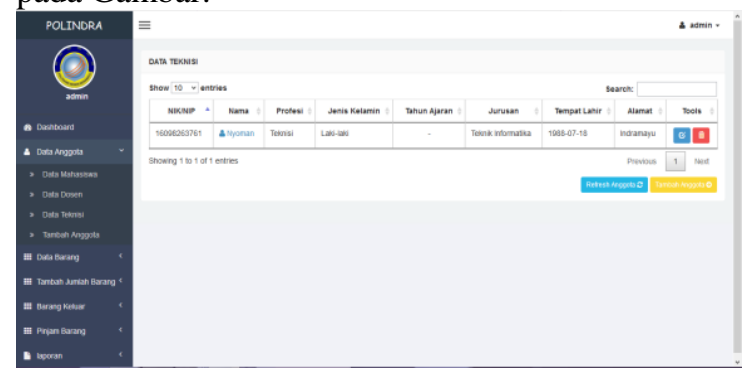

\section{Gambar 8. Halaman Data Anggota Teknisi}

\section{Halaman Tambah Anggota}

Halaman tambah anggota adalah sebuah form untuk menginputkan data-data anggota Politeknik Negeri Indramayu yang di inputkan oleh admin. Berikut adalah halaman tambah anggota dapat dilihat pada Gambar.

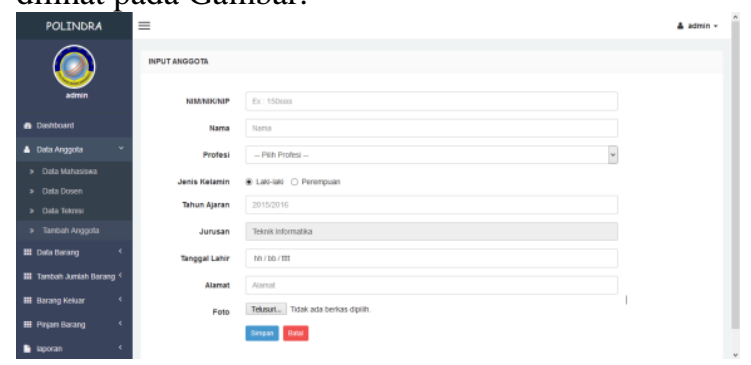

Gambar 9. Halaman Tambah Anggota

\section{Halaman Data Barang Tidak Habis Pakai}

Halaman ini merupakan stok barang dan bahan praktikum yang jenisnya tidak habis pakai yang tersedia di bengkel atau maintenance. Berikut adalah halaman data barang tidak habis pakai dapat dilihat pada Gambar.

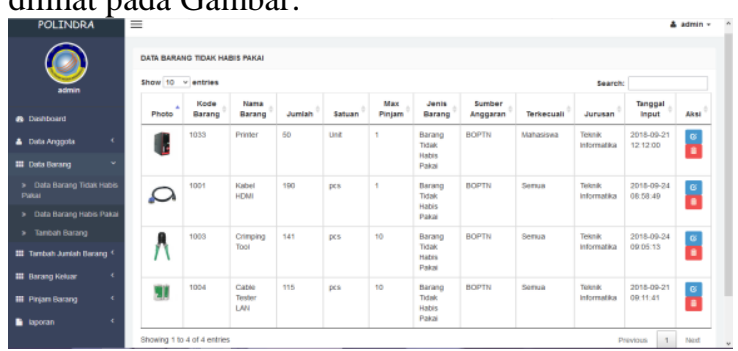

Gambar 10. Halaman Data Barang Tidak Habis Pakai

\section{Halaman Data Barang Habis Pakai}

Halaman ini merupakan stok barang dan bahan praktikum yang jenisnya habis pakai yang tersedia di bengkel atau maintenance. Berikut adalah halaman data barang habis pakai dapat dilihat pada Gambar.

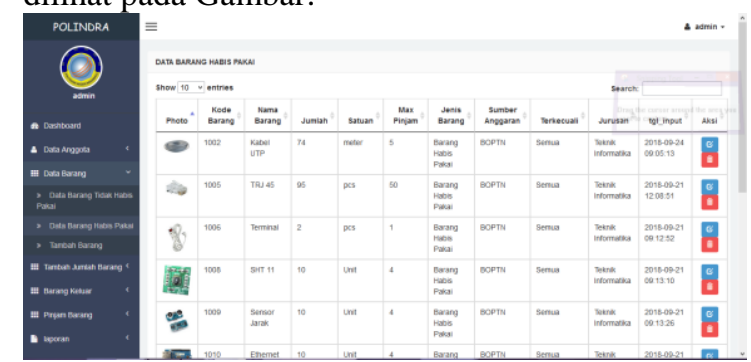

Gambar 11. Halaman Data Barang Habis Pakai

\section{Halaman Tambah Barang}

Halaman ini admin menginputkan form stok barang dan bahan praktikum yang tersedia di bengkel atau maintenance. Berikut adalah halaman tambah barang dapat dilihat pada Gambar.

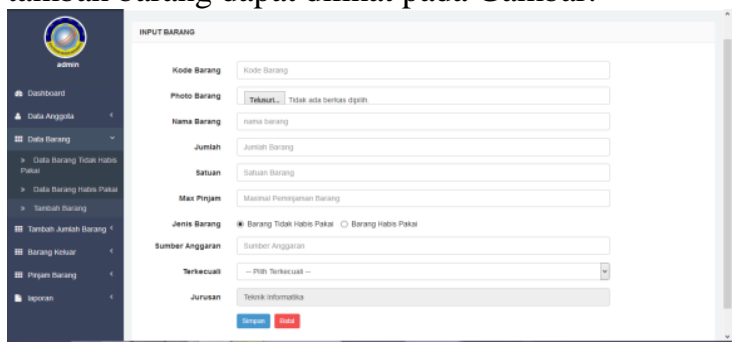

Gambar 12. Halaman Tambah Barang

\section{Halaman Data Jumlah Barang}

Halaman ini merupakan data penambahan stok barang dan bahan praktikum yang tersedia di bengkel atau maintenance. Berikut adalah halaman data jumlah barang dapat dilihat pada Gambar. 


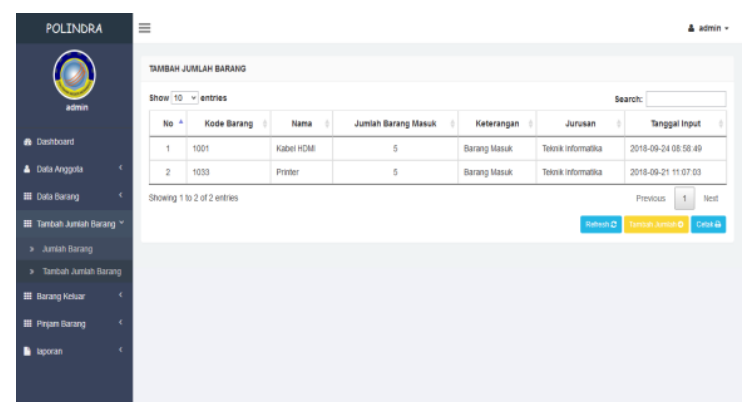

Gambar 13. Halaman Data Jumlah Barang

\section{Halaman Tambah Jumlah Barang}

Halaman ini admin menginputkan sebuah form untuk menambah jumlah stok barang dan bahan praktikum yang sudah tersedia di bengkel atau maintenance. Berikut adalah halaman tambah jumlah barang dapat dilihat pada Gambar.

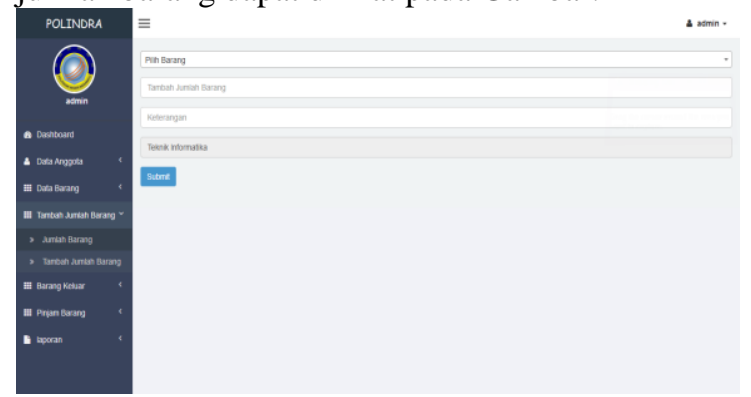

Gambar 14. Halaman Tambah Jumlah Barang

\section{Halaman Data Jumlah Barang Keluar}

Halaman ini merupakan data pengurangan stok barang dan bahan praktikum yang tersedia di bengkel atau maintenance. Berikut adalah halaman data jumlah barang keluar dapat dilihat pada Gambar.

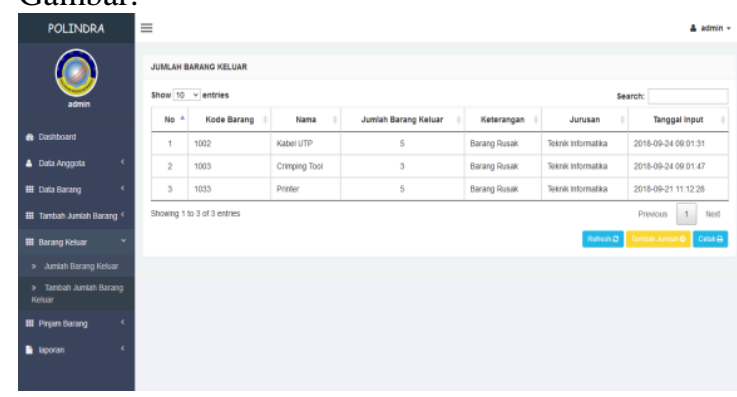

Gambar 15. Halaman Data Jumlah Barang Keluar

\section{Halaman Tambah Jumlah Barang Keluar}

Halaman ini admin menginputkan sebuah form jika ada stok barang dan bahan praktikum yang yang keluar dari bengkel atau maintenance. Berikut adalah halaman tambah jumlah barang keluar dapat dilihat pada Gambar.

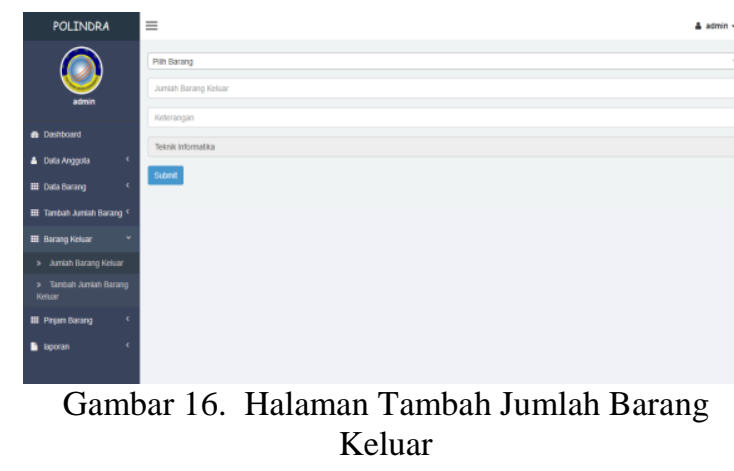

14. Halaman Data Pinjaman

Halaman berisi data peminjam barang untuk kegiatan praktek, button status fungsinya untuk mengetahui barang dan bahan praktikum sudah dikembalikan atau belum dikembalikan. Berikut adalah halaman data pinjman dapat dilihat pada Gambar.

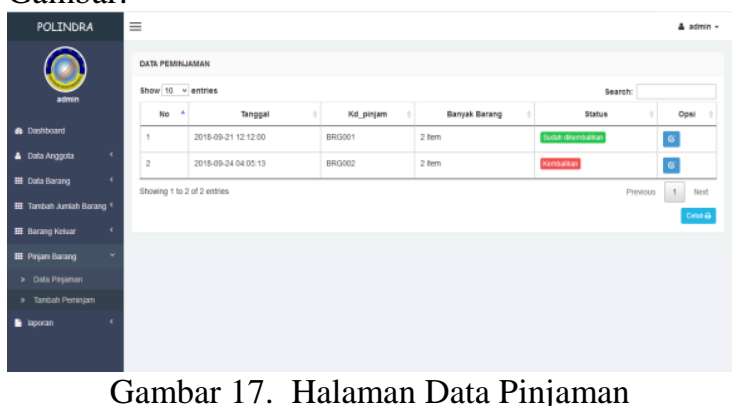

\section{Halaman Tambah Pinjaman}

Halaman ini merupakan halaman jika ada anggota yang ingin meminjam barang. Berikut adalah halaman tambah peminjam dapat dilihat pada Gambar.

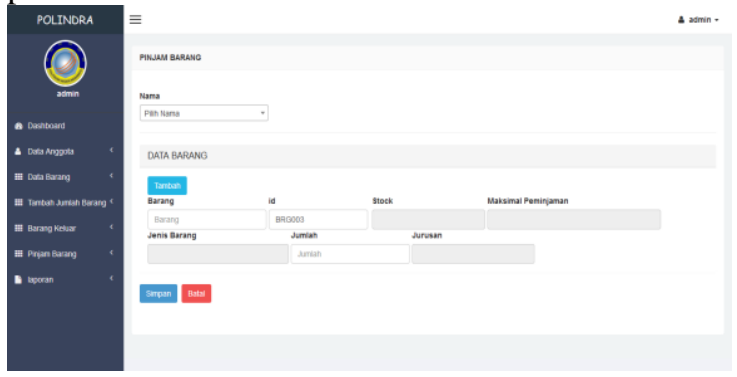

Gambar 18. Halaman Tambah Pinjaman

\section{Halaman Laporan Anggota}

Halaman ini data laporan Anggota setiap bulannya. Berikut adalah halaman laporan anggota dapat dilihat pada Gambar.

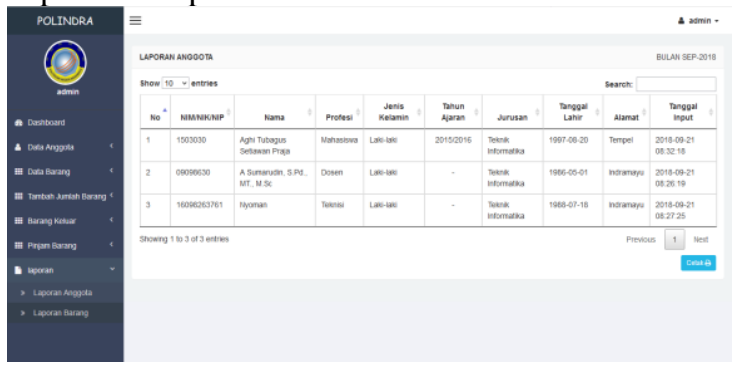

Gambar 19. Halaman Laporan Anggota 


\section{Halaman Laporan Barang}

Halaman ini data laporan barang setiap bulannya. Berikut adalah halaman laporan barang dapat dilihat pada Gambar.

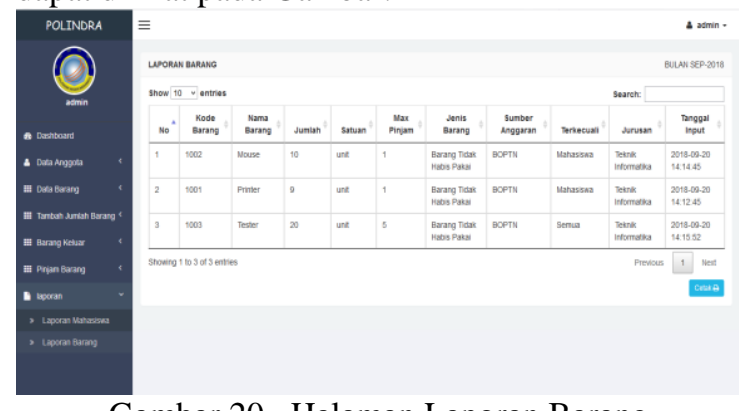

Gambar 20. Halaman Laporan Barang

\section{KESIMPULAN}

Kesimpulan yang didapat penulis setelah mengumpulkan, mengolah, menganalisa, mengimplementasi serta melakukan pengujian aplikasi adalah sebagai berikut.

1. Aplikasi ini dirancang mulai dari awal dengan cara mengumpulkan data-data melalui studi pustaka, metode observasi, analisa kegiatan admin, penyusunan flowchart, Entity Relationship Diagram (ERD), Unified Modelling Language (UML) dan pembuatan tabel sampai pemrograman.

2. Aplikasi ini dibuat dalam bentuk website sehingga dapat diakses dengan mudah oleh anggota (mahasiswa, dosen dan teknisi) dan admin.

3. Proses transaksi peminjaman dan pengembalian barang dan bahan praktikum terkomputerisasi.

\section{DAFTAR PUSTAKA}

[1] Ahmad, Indra. 2017. BAB II LANDASAN TEORI. Bandung: Universitas Komputer Indonesia.

[2] Andika, Dwiky. 2018. Pengertian Flowchart. https://www.it-jurnal.com. Diakses pada tanggal 4 Juni 2018.

[3] Asmara, Indra. 2015. PERANCANGAN WEBSITE UNTUK CV. TERAPIXEL TRIMEDIA PROMOTION SEBAGAI MEDIA PROMOSI. Jurnal Pendidikan Seni Rupa, Volume 3 Nomor 1 Tahun 2015, 155-164.

[4] Ferdika, Mikhael dan Heri Kuswara. 2017. Sistem Informasi Penjualan Berbasis Web Pada PT Era Makmur Cahaya Damai Bekasi. INFORMATION SYSTEM FOR EDUCATORS AND PROFESSIONALS Vol.1, No. 2, Hal. 175 -188.

[5] Fikri Setiadi, M. 2017. Kupas Tuntas Konsep Model Data Entity Relationship Diagram atau ERD. http://mfikri.com. Diakses pada tanggal 6 Juni 2018.
[6] Herianto, M.G. 2012. BAB II LANDASAN TEORI. Surabaya: STIKOM Surabaya.

[7] Kusnandar. 2017. BAB II LANDASAN TEORI. Bandung: Universitas Komputer Indonesia.

[8] N Sora. 2015. Pengertian UML Dan JenisJenisnya Serta Contoh Diagramnya. http://www.pengertianku.net. Diakses pada tanggal 2 Juni 2018.

[9] Rohman, Abdul. 2015. E-scheduling information systems maintenance of it assets (e-sismitas) di pt. Karya putra sukses. $\quad$ Skripsi. Tangerang: STMIK Raharja.

[10] Zaidi, Muhammad. 2015. PHP My Admin dan My SQL. http://muhammadzaidi.it.student.pens.ac.id/ . Diakses pada tanggal 6 Juni 2018. 